\title{
Drought tolerance indices and path-analysis in long staple cotton genotypes (G. barbadense)
}

\author{
Mahdy, E.E. ${ }^{1 *}$, S.F. Abou-Elwafa ${ }^{1}$, G.H. Abdel-Zahir ${ }^{2}$ \\ and N.I. Abdelrahman ${ }^{2}$ \\ ${ }^{1}$ Department of Agronomy, Faculty of Agriculture, Assiut University, Assiut, Egypt. \\ ${ }^{2}$ Agric.Res. Cen. Cotton Res. Ins., Egypt.
}

\begin{abstract}
Drought stress is a serious abiotic factor that adversely affects cotton yield and fiber properties. The objectives of this study were to screen several genotypes of cotton belong to Gossypium barbadense L. for drought tolerance, study drought indices, correlations, and path-coefficient analysis. Fourteen long- staple kinds of cottons cultivated, and obsolete cultivars were screened for drought tolerance at normal irrigation and drought- stressed experiments for two years. Mean squares indicated significant $(\mathrm{p} \leq 0.01)$ differences among genotypes in the separate and combined analysis. The effect of years showed significant $(p \leq 0.05$ to $p \leq 0.01)$ differences in most cases. The interaction of genotypes by years was significant for all traits except few cases. The reduction $\%$ caused by drought stress in SCY/P ranged from 31.44 to 39.39 with an average of 33.93. Among ten tolerant indices STI, MP, GMP, HM and DI could be considered the best tolerant indices to detect both of tolerant and susceptible genotypes. The correlation of SCY/P under normal irrigation was high with LY/P, Lint \%, NB/P, LI and BW, moderate with NS/B and upper half mean length, and low with DFF, Pressley index and negative with Micronaire reading. However, the picture was different under drought stress, in which drought affected lint rather than seeds. The direct and indirect effects of SCY/P components varied greatly under both environments, and LY/P, NB/P and NS/B should be considered as selection indices under normal irrigation, NB/P and NS/B under stress when selection practiced for SCY/P.
\end{abstract}

Keywords: Correlation; Drought indices; Drought tolerance; G. barbadense; Path-analysis.

\section{Introduction}

Drought stress is a serious abiotic factor limits crop production worldwide. Egypt suffers from water scarcity required for agriculture. Furthermore, it has become necessary to grow cotton in newly reclaimed soil and leave the old valley for other crops that cannot bear the lack of water. The drought stress significantly affects many agronomic traits like reduction in size and number of bolls per plant, plant height, above- ground fresh weight, seed

\footnotetext{
*Corresponding author: Ezzat E. Mahdy,

Email: ezzat.mahdy@agr.au.edu.eg

Received: June 21, 2021; Accepted: July 15, 2021;

Published online: July 30, 2021

(C) Published by South Valley University.

This is an open access article licensed under 다)(ㄱ)(이
}

cotton yield etc. (Malik et al., 2006). The yield and fiber traits of cotton are adversely influenced by moisture stress. Thus, it is a great issue for cotton physiologists and breeders to develop water stress tolerable genotypes (Veesar et al., 2018). Mahdy et al. (2008) studied three irrigation treatments: 80, 100 and $120 \%$ evapotranspiration (Et) at sandy calcareous and clay soils. The effect of irrigation treatments was significant $(p \leq 0.01)$, Dandara and Giza 83 were the best tolerant cultivars for all traits. The interaction of irrigation $\mathrm{x}$ cultivars was highly significant for all traits except for lint \%, seed and lint indices at both locations and boll weight at the sandy soil. Turkey (2012) noted genotypic variation

Between locations. Drought stress 
adversely affected all the growth and yield and

Ahmadikhah, 2009; Mahdi et al., 2014; Sahito et al., 2015; Hamoud et al., 2016; Bakhsh et al., 2019). Furthermore, fiber quality was significantly affected by drought levels (Gao et al., 2020).

Geometric mean productivity (GMP), mean productivity (MP), and stress tolerance (STI) index indices were able to discriminate drought-sensitive and tolerant genotypes (Singh et al., 2016). In wheat found that STI, MP and GMP were the more efficient drought tolerance indicators in identifying high yielding genotypes under normal and drought stress conditions (Fouad, 2018). Yehia (2020) stated that the indices of MP, GMP, STI, YI and HM (harmonic mean) were considered as a better predictor of yield under stress (Ys) and under normal condition (Yp) than the other indices. Many authors reported positive correlations between yield and its components in most cases, and correlations among yield traits were higher in normal irrigation as compared with water stress (Farooq et al., 2014; Reddy et al., 2015; Joshi and Patil, 2018; Khokhar et al., 2017; Abdel-Monaem et al., 2018; Nawaz et al., 2019; Amein, 2020). The true picture of that correlation between seed cotton yield and its contributing traits was reflected from direct and indirect effects to perceive the most influencing characters to be utilized as selection criteria in the cotton breeding program (Tulasi et al., 2012). Bolls plant $-{ }^{1}$ had maximum direct effect followed by boll weight, seed index and lint index (Ahsan et al., 2015; Reddy et al., 2015). Nawaz et al. (2019) found that the maximum direct positive effect of lint weight was (2.6005) on seed cotton yield followed by fiber fineness (1.2628), seed index (1.1449) and bolls/plant (1.0027). The objectives of this study were to screen several genotypes of cotton belong to its components (Alishah and

Gossypium barbadense L. for drought tolerance, the ability of ten selection indices to identify drought-resistant cultivars under normal irrigation and drought stressful environmental conditions, and study correlations and path-coefficient analysis among seed cotton yield and its components.

\section{Materials and methods}

The experiments were carried out at Shandaweel Research Station, Sohag, Agricultural Research Center (A.R.C), Egypt during the two-summer successive growing seasons of 2018 and 2019. Fourteen cotton varieties (Gossypium barbadense L.) and promising lines were evaluated under water stress and normal irrigation conditions.

\subsection{Evaluation}

\subsubsection{Season 2018 (first season)}

The genotypes shown in Table 1 were evaluated under normal irrigation and water stress conditions. All these genotypes are long - staple fiber. Pure seeds of these genotypes were obtained from Cotton Research Institute, Agricultural Research Center at Giza, Egypt.

The fourteen genotypes shown in Table 1 were sown on March $25^{\text {th }}$ in a randomized complete block design of three replications. Each plot consisted of one row, four-meter-long, $0.6 \mathrm{~m}$ apart and $40 \mathrm{~cm}$ between hills within a row. One stripe five meters in width was left without planting between the normal irrigation (irrigation as required) and drought- stressed (irrigation just before wilting point) experiments to prevent water seepage. After full emergence, seedlings were thinned to one plant per hill. 
Table 1. The name, pedigree, and the main characteristics of these genotypes.

\begin{tabular}{|c|c|c|}
\hline Genotype & Pedigree & Characteristics \\
\hline Giza 80 & G. $66 \times$ G. 73 & $\begin{array}{l}\text { Long- staple variety. It is high yield and Lint } \\
\text { percentage. }\end{array}$ \\
\hline Giza 83 & G. $72 \times$ G.67 & $\begin{array}{l}\text { A long- staple variety, early maturity, good yarn and tolerant } \\
\text { to high temperature }\end{array}$ \\
\hline Giza 85 & G. $67 \times$ CB 58 & $\begin{array}{l}\text { A long- staple variety, characterized by high yield and } \\
\text { earliness variety. }\end{array}$ \\
\hline Giza 90 & Dandara $\times$ G.83 & $\begin{array}{l}\text { A long- staple cotton variety, early maturity, high yield, good } \\
\text { yarn, and tolerant to high temperature. }\end{array}$ \\
\hline Giza 95 & $\begin{array}{l}{[(\mathrm{G} .83 \times(\mathrm{G} .75 \times} \\
5844)) \times \text { G. } 80]\end{array}$ & $\begin{array}{l}\text { A long- staple cotton variety, high yield, high lint percentage, } \\
\text { early maturity, and heat tolerance. }\end{array}$ \\
\hline Dandara & $\begin{array}{l}\text { Selected from } \\
\text { Giza-3 }\end{array}$ & Long- staple variety (obsolete). \\
\hline Ashmouni & Giza 1 & Long- staple variety (obsolete). \\
\hline Australian & & From Australia belong to Gossypium barbadense L. \\
\hline Krashinki & & From Russia belong to Gossypium barbadense L. \\
\hline Giza $90 \times$ Australian & G. $90 \times$ Australian & $\begin{array}{l}\text { A long- staple cotton variety, early maturity, high yield, high } \\
\text { L\% and tolerant to high temperature }\end{array}$ \\
\hline$[($ Giza 91×Giza 90) $\times$ Giza 80] $(\mathrm{A})$ & & Promising line in 12 generation \\
\hline [(Giza 90× Australian) $\times$ Giza 85$]($ B $)$ & & Promising line in 14 generation \\
\hline $\begin{array}{l}{[(\text { Giza } 90 \times \text { Australian }) \times\{(\text { Giza } 83 \times \text { Giza }} \\
72) \times \text { Dandara }\}](C)\end{array}$ & & Promising line in 13 generation \\
\hline $\begin{array}{l}{[(\text { Giza } 90 \times \text { Australian }) \times\{(\text { Giza } 83 \times \text { Giza }} \\
75) \times 5584\}](\text { D })\end{array}$ & & Promising line in 12 generation \\
\hline
\end{tabular}

\subsubsection{Soil Samples}

Disturbed and undisturbed soil samples were collected from plots of each irrigation level at vertical depths of 0-15, 15-30, 30-45 and 45-60 $\mathrm{cm}$ before and after irrigation. Measurement of soil moisture content was carried out using the difference in the soil moisture content in each layer before and after irrigation using the gravimetric method. The sum of the soil moisture deficits of the four layers were added in the next irrigation to reach the field capacity.

\subsubsection{Soil physical and chemical properties}

The soil physical and chemical properties were measured at Shandaweel Research Station
Lab., Sohag, Agricultural Research Center (A.R.C), Egypt as the following.

Particle size distribution according to Gee and Bauder (1986). Field capacity was determined according to Cassel and Nielsen (1986). Available water was calculated from the values of field capacity and wilting point. Bulk density was determined according to (Blake and Hartge, 1986). The soil moisture constant of the experimental field i.e., field capacity, wilting point and available soil moisture were determined and were $30.69 \%, 12.63 \%$, and18.06 \% respectively. The soil was clay loamy in texture with a bulk density of 1.22 $\mathrm{g} / \mathrm{cm}^{3}$ and $\mathrm{pH}$ 7.9. Soil samples were taken from each $15 \mathrm{~cm}$ depth up to $60 \mathrm{~cm}$ from the ground surface. The amount of water 
consumed during each irrigation period was obtained from the difference between soil moisture content before the following irrigation and that of the preceding one according to the following formula as described by Israelsen and Hansen (1962). Soil moisture constants and Soil physical and chemical properties were measured and recorded in Tables 2 and 3.

\subsubsection{Actual water consumptive use 'WCU' (Actual evapotranspiration)}

Water consumptive use (actual evapotranspiration) was computed as the difference in soil moisture in the soil samples taken before and after irrigations. It was affected by the amounts and intervals of irrigation. It was calculated according to the equation of Israelsen and Hansen (1962) as follows:

$$
\mathrm{CU}=\mathrm{D} \times \mathrm{Bd} \times(\mathrm{Q} 2-\mathrm{Q} 1 / 100)
$$

Where:

$\mathrm{CU}=$ actual water consumptives use in (mm).

$\mathrm{D}=$ irrigation soil depth
$\mathrm{Bd}=$ bulk density of soil $\left(\mathrm{g} \mathrm{cm}^{-3}\right)$

$\mathrm{Q} 1$ = soil moisture percent before next irrigation.

Q2 = soil moisture percent after irrigation by $48 \mathrm{~h}$.

$\mathrm{CU}\left(\mathrm{m}^{3} \mathrm{fed}^{-1}\right)=\mathrm{CU}(\mathrm{mm}) \times 4.2$

To obtain the actual water consumptive use $\mathrm{CU}$, the soil moisture percentage was determined gravimetrically on a dry basis just before irrigation. Soil samples for moisture determination were taken from each $15 \mathrm{~cm}$ depth up to $60 \mathrm{~cm}$ from the soil surface by a regular auger. The samples were weighted and then oven- dried. The amount of water consumed in each irrigation interval was obtained from the difference between soil content before the following irrigation and field capacity.

At flowering self-pollination was done for the best plants in the plot, days to first flower (DFF) was recorded for five plants/row. Before picking, 10 open sound bolls were picked from each plot to measure boll weight (BW, g), seed index (SI, g), lint index (LI, g).

Table 2. Soil profile and physical analysis of the experimental site at Shandaweel Agricultural Research Station.

\begin{tabular}{|c|c|c|c|c|c|c|c|c|c|c|}
\hline \multirow{2}{*}{$\begin{array}{l}\text { depth } \\
(\mathrm{cm})\end{array}$} & \multicolumn{4}{|c|}{ Particle distribution $\%$} & \multirow[t]{2}{*}{ Texture } & \multirow{2}{*}{$\begin{array}{c}\text { Hydraulic } \\
\text { Conductivity } \\
, \mathrm{cm} / \mathrm{h}\end{array}$} & \multirow{2}{*}{$\begin{array}{c}\text { Bulk } \\
\text { density, } \\
\mathrm{gm} / \mathrm{cm}^{3}\end{array}$} & \multicolumn{3}{|c|}{ Soil water content, $\%$} \\
\hline & $\begin{array}{c}\text { Course } \\
\text { sand }\end{array}$ & $\begin{array}{l}\text { Fine } \\
\text { sand }\end{array}$ & Silt & Clay & & & & Saturation & $\begin{array}{c}\text { Field } \\
\text { Capacity }\end{array}$ & $\begin{array}{c}\text { Permanent } \\
\text { wilting point }\end{array}$ \\
\hline $\begin{array}{c}\text { A (1- } \\
15)\end{array}$ & 7.80 & 16.20 & 38.20 & 37.80 & $\begin{array}{l}\text { Clay } \\
\text { Loam }\end{array}$ & 2.90 & 1.34 & 56 & 27.60 & 15.50 \\
\hline $\begin{array}{c}\text { B (15- } \\
30)\end{array}$ & 6.90 & 15.50 & 39.50 & 38.10 & $\begin{array}{l}\text { Clay } \\
\text { loam }\end{array}$ & 2.90 & 1.36 & 50 & 28 & 14.1 \\
\hline $\begin{array}{c}\mathrm{C}(30- \\
45)\end{array}$ & 10.00 & 35.50 & 45.20 & 9.30 & Loam & 11.50 & 1.56 & 27.1 & 12.2 & 7.2 \\
\hline $\begin{array}{c}\mathrm{D}(45- \\
60)\end{array}$ & 15.50 & 33.90 & 42.10 & 8.50 & Loam & 10.70 & 1.57 & 29.3 & 15.1 & 6.4 \\
\hline
\end{tabular}

Table 3. concentration of soil available macro-and microelements, electrical conductivity (EC), $\mathrm{PH}$, and calcium carbonate in the site at Shandaweel Agricultural Research Station.

\begin{tabular}{|c|c|c|c|c|c|c|c|c|c|c|c|}
\hline \multirow[t]{2}{*}{ Season } & \multicolumn{7}{|c|}{ Concentration, $\mathrm{mg} / 100 \mathrm{~g}$ soil } & \multirow[b]{2}{*}{$\begin{array}{c}\mathrm{EC}, \\
\mathrm{Ds} / \mathrm{m}(1: 5)\end{array}$} & \multirow[b]{2}{*}{$\mathrm{pH}$} & \multirow[b]{2}{*}{$\mathrm{N} \%$} & \multirow[b]{2}{*}{$\mathrm{CaCO}_{3} \%$} \\
\hline & HCO-3 & $\mathrm{Cl}^{-}$ & $\mathrm{SO} 4=$ & $\mathrm{Ca}^{++}$ & $\mathrm{Mg}^{++}$ & $\mathrm{Na}^{+}$ & $\mathrm{K}^{+}$ & & & & \\
\hline 2018 & 0.30 & 0.88 & 1.02 & 0.52 & 0.26 & 1.26 & 0.16 & 0.263 & 7.3 & 0.20 & 1.26 \\
\hline 2019 & 0.26 & 0.79 & 1 & 0.50 & 0.24 & 1.17 & 0.14 & 0.246 & 7.8 & 0.17 & 1.41 \\
\hline 2020 & 0.22 & 0.70 & 0.98 & 0.48 & 0.22 & 1.08 & 0.12 & 0.229 & 8.3 & 0.14 & 1.56 \\
\hline
\end{tabular}

At the end of the season the following cotton yield /plant (SCY/P, g), lint yield /plant characters were recorded for each plot: seed (LY/P, g), lint percentage (Lint \%), number of 
bolls/plant (NB/P), and number of seeds/boll (NS/B). The technological properties were determined for a mixed sample from each replicate; Micronaire reading (MR), fiber strength as Pressley index (PI) measured by the H.V.I instrument and Upper half mean length, $\mathrm{mm}$ as measured by the H.V.I instrument (UHM)

Season 2019 (second season), the genotypes evaluated under water stress and normal irrigation conditions as in the previous season 2018.

\subsection{Statistical analysis}

Statistical analysis was performed on plot mean basis and significance tests as outlined by Steel et al., 1997. The analysis of variance and covariance was calculated by Miller et al, (1958). The path coefficient analysis was done as outlined by Dewey and Lu (1959). Ten drought tolerance indices were calculated based on grain yield under drought (Ys), irrigated (Yp) conditions and the stress intensity $\mathrm{SI}=1-(\mathrm{Ys} / \mathrm{Yp})$.

1- Stress susceptibility index $(\mathrm{SSI})=$ [1- (Ys/ Yp)]/SI (Fischer and Maurer, 1978) 2- Stress tolerance index $(\mathrm{STI})=\mathrm{Ys} . \mathrm{Yp} /(\mathrm{Yp})^{2}$ (Fernandez, 1992)

3- Mean productivity $(\mathrm{MP})=(\mathrm{Ys}+\mathrm{Yp}) / 2$ (Rosielle and Hamblin, 1981)

4- Geometric mean productivity $(\mathrm{GMP})=$ $\sqrt{ }$ Ys.Yp (Fernandez, 1992)

5- Tolerance index $(\mathrm{TOL})=\mathrm{Yp}-\mathrm{Ys}$ (Rosielle and Hamblin, 1981)

6- Yield stability index $(\mathrm{YSI})=\mathrm{Ys} / \mathrm{Yp}$ (Bouslama and Schapaugh, 1984)

7- Harmonic mean $(\mathrm{HM})=$

$[2(\mathrm{Yp} \mathrm{Ys})] /(\mathrm{Yp}+\mathrm{Ys})$ (Chakherchaman et al., 2009)

8- Sensitivity drought index $(\mathrm{SDI})=$

$(\mathrm{Yp}-\mathrm{Ys}) / \mathrm{Yp}$ (Farshadfar and Javadinia, 2011)

9- Drought resistance index (DI) = [Ys (Ys/Yp)]/Ys (Lan, 1988)

10- Relative drought index $(\mathrm{RDI})=(\mathrm{Ys} / \mathrm{Yp})$ (Ys/ Yp) (Fischer et al., 1998)

\section{Results and discussion}

\subsection{Tolerance of Egyptian cotton genotypes to water stress condition}

Mean squares of all the studied traits under normal and stressed conditions in year1 and year2 and their combined (Tables 4 and 5) indicated significant $(\mathrm{p} \leq 0.01)$ differences among genotypes in the separate and combined analysis. The effect of years showed significant $(p \leq 0.05$ to $p \leq 0.01)$ differences between the two seasons for all traits except NB/P, NS/B, DFF and Micronaire reading under normal irrigation, and for all traits except for LY/P and lint\% under stressed condition. These results show that the stability of cotton characters differed from year to year. Furthermore, the interaction of genotypes by years was significant for all traits except for staple length and strength under normal irrigation, and for all traits except for lint $\%$ under drought stress. Except for fiber length and strength, most of the variability was caused by genotypes rather than years and their interactions with genotypes. These results indicate the differential response of most cotton traits to soil moisture and seasons. Mahdi et al. (2014) noted that seed cotton yield was reduced by drought stress (\%47.03), Sahito et al. (2015) showed that all the growth and yield components of cotton were significantly $(\mathrm{P}<0.01)$ affected by varieties and irrigation frequencies, Hamoud et al. (2016) found significant $(p \leq 0.01)$ genetic differences between cotton well-watered and water-stressed treatments, Gao et al. (2020) noted that fiber quality was significantly affected by drought level, Shilpa and Chandrasekhar (2020) found that fiber fineness and bundle strength decrease in inferior direction as reduction of soil moisture levels.

Means of all traits at normal irrigation and drought stress conditions in both years, their combined, and reduction $\%$ are shown in Table 6. The combined means indicated that Giza95 showed the highest SCY/P (127.32 g) and Cgenotype was the lowest $(68.89 \mathrm{~g})$ under 
normal irrigation. The reduction \% caused by drought stress in SCY/P ranged from 31.44 (Dgenotype) to 39.39 (karashinki) with an average of 33.93. Giza 95 showed the best performance under both environments for SCY/P, LY/P, Lint\%, NB/P, SI, and LI, while Giza 90 was the best for fiber length (upper half mean length), and the Australian genotype was the best in fiber strength as measured in Pressley index. The reduction\% in LY/P caused by drought stress was slightly higher than in SCY/P indicating that lint was more affected than seeds. In consequence, the lint index was more affected by drought than the seed index. Lint\% was slightly affected due to that drought stress affected both of lint and seeds. The reduction in yields could be mainly due to the decrease in lint index, boll weight and seed index rather than a decrease in bolls/plant. None of the genotypes was the best in all traits. These results confirm the significant differences obtained among genotypes. Many authors reported the effect of the environment on cotton traits. Turkey (2012) noted genotypic variation between locations. Mahdi et al. (2014) found that seed cotton yield was reduced by drought stress (\%47.03) and added that it was probably due to a decrease of bolls/plant. Sahito et al. (2015) showed that all the growth and yield components of cotton were significantly $(\mathrm{P}<$ 0.01 ) affected by varieties and irrigation frequencies. Bakhsh et al. (2019) noted that water stress caused a reduction of $14 \%$ in days to first flower formation, $27 \%$ in number of bolls/ plants, $14 \%$ in boll weight and $37 \%$ in seed cotton yield.

\subsection{Drought Tolerance Indices}

The drought tolerance indices (SSI, STI, MO, GMP, TOL, YSI, HM, SDI, DI and SDI) were calculated based on the combined mean of SCY/P under irrigation (Yp) and under drought stress (Ys) and ranked (Table 7). The low rank indicates tolerance and the high indicates susceptibility to drought. The ranks mean was the lowest for Giza 95 followed by Giza 90 and Giz90 × Aus indicating tolerance to drought stress. These genotypes rank the first, second, and the third for drought tolerance indices STI, MP, GMP, HM and DI. Conversely, the highest ranks mean (towards susceptibility) was for Dandara, Ashmouni and Karashinki, their ranks ranged from 9 to 14 for SSI, STI, MP, GMP, YSI, HM, DI and RDI drought indicators. Therefore, STI, MP, GMP, HM and DI detected both of tolerant and susceptible genotypes and could be considered the best tolerant indices. Furthermore, for the 14 studied genotypes, the simple correlation between the ranks of Yp and Ys with ranks mean were 0.999 and 0.993 , respectively indicating that the information concerning to drought tolerance could be derived from the performance of a genotype under normal and stress environments. Fouad (2018) found that STI, MP and GMP were the more efficient drought tolerance indices in identifying highyielding genotypes under normal and drought stress conditions. Yehia (2020) studied the ability of 13 drought tolerance indicators in 24 cottons (G. barbadense L.) and noted that MP, GMP, STI, YI (yield index) and HM were the best indicators to detect drought tolerance genotypes.

\subsection{Phenotypic correlations among traits}

The phenotypic and genotypic correlations among traits over the two years under normal irrigation and under stressed conditions were estimated. The genotypic correlation under stressed condition, exceeded the unity in many cases because of the mean squares of genotype by years was larger than mean squares of genotypes (BW, SI, NS/B and DFF- Table5), which diminished the genetic variance (denominator of correlation). Therefore, the genotypic correlations among traits were omitted. The phenotypic correlations are shown in Table 8. The correlation of SCY/P under normal irrigation was high with LY/P, Lint \%, NB/P, LI and BW, moderate with NS/B and upper half mean length, and low with DFF, Pressley index and negative with Micronaire reading. 
Mahdy et al.,

Table 4. Mean squares of the studied traits under normal irrigation in the two years and their combined.

\begin{tabular}{|c|c|c|c|c|c|c|c|c|c|c|c|c|c|}
\hline S.O.V. & df & SCY/P & $\mathrm{LY} / \mathrm{P}$ & $\mathrm{L} \%$ & NB & BW & SI & LI & NS/B & D.F.F. & $\mathrm{MIC}$ & Length & Strength \\
\hline \multicolumn{14}{|c|}{ Year 1} \\
\hline Reps & 2 & 14.54 & 0.17 & 2.09 & 2.27 & 0.01 & 0.01 & 0.13 & 0.61 & 1.60 & 0.01 & 0.04 & 0.001 \\
\hline Genotypes (G) & 13 & $961.57^{* *}$ & $183.99^{* *}$ & $3.89^{* *}$ & $47.86^{* *}$ & $0.19^{* *}$ & $0.72^{* *}$ & $0.47^{* *}$ & $8.71^{* *}$ & $55.20^{* *}$ & $0.69^{* *}$ & $30.59^{* *}$ & $1.21^{* *}$ \\
\hline Error & 26 & 15.91 & 2.69 & 0.52 & 1.72 & 0.004 & 0.01 & 0.04 & 0.14 & 0.70 & 0.01 & 0.31 & 0.007 \\
\hline \multicolumn{14}{|c|}{ Year 2} \\
\hline Reps & 2 & 21.32 & 2.99 & 0.08 & 5.88 & 0.003 & 0.07 & 0.02 & 0.13 & 3.43 & 0.01 & 2.43 & 0.05 \\
\hline Genotypes (G) & 13 & $877.64^{* *}$ & $193.79^{* * *}$ & $9.54^{* *}$ & $43.18^{* *}$ & $0.17^{* *}$ & $0.82^{* *}$ & $1.09^{* *}$ & $4.60^{* *}$ & $57.73^{* *}$ & $0.55^{* *}$ & $28.90^{* * *}$ & $230.14^{* * *}$ \\
\hline Error & 26 & 16.02 & 2.87 & 0.90 & 3.37 & 0.01 & 0.02 & 0.08 & 0.49 & 0.66 & 0.01 & 0.27 & 0.01 \\
\hline \multicolumn{14}{|c|}{ Combined } \\
\hline Years (Y) & 1 & $181.75^{* *}$ & $65.02^{* *}$ & $12.45^{* *}$ & 0.02 & $0.14^{* *}$ & $0.09^{*}$ & $1.04^{* *}$ & 0.97 & 0.78 & 0.02 & $9.94^{* *}$ & $0.26^{* *}$ \\
\hline Reps/Year & 4 & 14.94 & 1.58 & 1.09 & 4.07 & 0.01 & 0.04 & 0.07 & 0.37 & 2.51 & 0.01 & 1.23 & 0.02 \\
\hline Genotypes (G) & 13 & $1791.95^{* *}$ & $368.96^{* *}$ & $11.46^{* *}$ & $84.13^{* *}$ & $0.34^{* *}$ & $1.44^{* *}$ & $1.43^{* *}$ & $11.64^{* *}$ & $108.97^{* *}$ & $1.20^{* *}$ & $59.31^{* *}$ & $2.52^{* *}$ \\
\hline $\mathrm{G} \times \mathrm{Y}$ & 13 & $47.26^{* * *}$ & $8.82^{* *}$ & $1.97^{* *}$ & $6.91^{* *}$ & $0.03^{* *}$ & $0.10^{* *}$ & $0.13^{*}$ & $1.66^{* *}$ & $3.97^{* *}$ & $0.04^{* *}$ & 0.17 & 0.01 \\
\hline Error & 52 & 15.96 & 2.78 & 0.71 & 2.55 & 0.01 & 0.02 & 0.06 & 0.31 & 0.68 & 0.01 & 0.29 & 0.01 \\
\hline Pheno. Var. & - & 298.66 & 61.02 & 1.91 & 14.02 & 0.06 & 0.24 & 0.24 & 1.94 & 18.16 & 0.20 & 9.89 & 0.42 \\
\hline Geno. Var. & - & 290.78 & 60.02 & 1.58 & 12.87 & 0.05 & 0.22 & 0.22 & 1.66 & 17.50 & 0.19 & 9.86 & 0.42 \\
\hline
\end{tabular}

*, **, significant at 0.05 and 0.01 level of probability, respectively.

Table 5. Mean squares of the studied traits under water stress in the two years and their combined.

\begin{tabular}{|c|c|c|c|c|c|c|c|c|c|c|c|c|c|}
\hline S.O.V. & $\mathrm{df}$ & SCY/P & $\mathrm{LY} / \mathrm{P}$ & $\mathrm{L} \%$ & NB & BW & SI & LI & NS/B & D.F.F. & MIC & Length & Strength \\
\hline \multicolumn{14}{|c|}{ Year 1} \\
\hline Reps & 2 & 105.42 & 10.27 & 0.72 & 27.70 & 0.001 & 0.004 & 0.04 & 0.03 & 0.45 & 0.07 & 0.72 & 0.002 \\
\hline Genotypes (G) & 13 & $461.78^{* *}$ & $93.69^{* *}$ & $12.00^{* *}$ & $63.02^{* *}$ & $0.14^{* *}$ & $0.64^{* *}$ & $0.74^{* *}$ & $7.00^{* *}$ & $34.83^{* *}$ & $0.37^{* *}$ & $24.15^{* *}$ & $0.94^{* *}$ \\
\hline Error & 26 & 19.49 & 2.26 & 1.10 & 6.48 & 0.006 & 0.01 & 0.05 & 0.48 & 0.71 & 0.005 & 0.26 & 0.008 \\
\hline \multicolumn{14}{|c|}{ Year 2} \\
\hline Reps & 2 & 113.35 & 7.85 & 2.43 & 46.93 & 0.01 & 0.04 & 0.03 & 0.66 & 2.17 & 0.02 & 0.05 & 0.02 \\
\hline Genotypes (G) & 13 & $414.61^{* *}$ & $87.30^{* *}$ & $13.50^{* *}$ & $64.51^{* *}$ & $0.15^{* *}$ & $0.75^{* *}$ & $0.91^{* *}$ & $11.30^{* * *}$ & $23.52^{* *}$ & $0.34^{* *}$ & $15.39^{* *}$ & $0.83^{* *}$ \\
\hline Error & 26 & 18.14 & 1.80 & 1.18 & 15.11 & 0.01 & 0.01 & 0.05 & 0.79 & 0.63 & 0.003 & 0.26 & 0.01 \\
\hline \multicolumn{14}{|c|}{ Combined } \\
\hline Years (Y) & 1 & $331.00^{\text {** }}$ & 3.18 & 74.53 & $66.63^{* *}$ & $3.48^{* *}$ & $0.11^{* *}$ & $11.17^{* *}$ & $8.97^{* *}$ & $3574.39^{* * *}$ & $66.76^{* * *}$ & $93.25^{* *}$ & $12.85^{* *}$ \\
\hline Reps/Year & 4 & 98.57 & 9.45 & 46.19 & 29.85 & 0.00 & 0.01 & 0.12 & 0.31 & 6405.89 & 0.06 & 0.28 & 0.02 \\
\hline Genotypes (G) & 13 & $1002.65^{* *}$ & $194.32^{* *}$ & $15.25^{* *}$ & $194.27^{* *}$ & $4.80^{* *}$ & $1.32^{* *}$ & $13.07^{* *}$ & $44.41^{* *}$ & $128.92^{* *}$ & $70.53^{* *}$ & $63.13^{* *}$ & $9.74^{* *}$ \\
\hline $\mathrm{G} \times \mathrm{Y}$ & 13 & $152.01^{* * *}$ & $20.74^{* *}$ & 2.96 & $96.82^{* *}$ & $4.91^{* *}$ & $1.49^{* *}$ & $8.77^{* *}$ & $62.59^{* * *}$ & $613.44^{* *}$ & $70.11^{* * *}$ & $40.14^{* *}$ & $9.02^{* *}$ \\
\hline Error & 52 & 19.48 & 2.44 & 42.10 & 5.89 & 0.01 & 0.01 & 0.11 & 0.57 & 40.34 & 0.01 & 0.26 & 0.01 \\
\hline Pheno. Var. & - & 167.11 & 32.39 & 2.54 & 32.38 & 0.80 & 0.22 & 2.18 & 7.40 & 21.49 & 0.07 & 10.52 & 0.12 \\
\hline Geno. Var. & - & 141.77 & 28.93 & 2.05 & 16.24 & -0.02 & -0.03 & 0.72 & -3.03 & -80.49 & 11.76 & 3.83 & 1.62 \\
\hline
\end{tabular}

*, **, significant at 0.05 and 0.01 level of probability, respectively. 
Table 6. Minimum (Min) and maximum (Max) combined means and reduction\% (Red\%), the best (BG) and the lowest performance genotype (LG) under normal irrigation(N) and drought stress(S) for the studied traits.

\begin{tabular}{|c|c|c|c|c|c|c|c|c|c|c|c|c|c|c|c|}
\hline \multirow[t]{2}{*}{ Item } & \multicolumn{3}{|c|}{$\mathrm{SCY} / \mathrm{P}, \mathrm{g}$} & \multirow[t]{2}{*}{ BG } & \multirow[t]{2}{*}{ LG } & \multicolumn{3}{|c|}{ LY/P, g } & \multirow[t]{2}{*}{$\mathrm{BG}$} & \multirow[t]{2}{*}{ LG } & \multicolumn{3}{|c|}{ Lint $\%$} & \multirow[t]{2}{*}{ BG } & \multirow[t]{2}{*}{$\mathrm{LG}$} \\
\hline & Min & Max & Average & & & Min & Max & Average & & & Min & Max & Average & & \\
\hline $\mathrm{N}$ & 68.89 & 127.32 & 96.00 & G.95 & C-g & 25.04 & 51.44 & 36.41 & G.95 & C-g & 35.28 & 40.41 & 37.71 & G.95 & Kar. \\
\hline S & 46.51 & 85.12 & 63.48 & G.95 & C-g & 15.87 & 33.49 & 23.13 & G.95 & Kar. & 33.21 & 39.34 & 36.18 & G.95 & Aus. \\
\hline $\operatorname{Red} \%$ & 31.44 & 39.39 & 33.93 & & & 30.34 & 43.15 & 36.65 & & & -2.03 & 9.01 & 4.07 & & \\
\hline \multirow[t]{2}{*}{ Item } & \multicolumn{3}{|c|}{$\mathrm{NB} / \mathrm{P}$} & BG & LG & \multicolumn{3}{|c|}{$\mathrm{BW}, \mathrm{g}$} & BG & LG & \multicolumn{3}{|c|}{ SI, g } & BG & LG \\
\hline & Min & Max & Average & & & Min & Max & Average & & & Min & Max & Average & & \\
\hline $\mathrm{N}$ & 27.73 & 39.80 & 35.14 & G.95 & C-g & 2.41 & 3.20 & 2.72 & G.95 & Aus. & 9.19 & 10.64 & 9.91 & G. 80 & C-g \\
\hline S & 24.44 & 40.77 & 30.26 & G.90×Aus. & C-g & 1.84 & 2.45 & 2.10 & G.95 & Kar. & 7.27 & 8.77 & 7.94 & G. 80 & G. 83 \\
\hline $\operatorname{Red} \%$ & -5.21 & 23.10 & 14.01 & & & 14.07 & 36.94 & 22.67 & & & 17.92 & 27.78 & 20.79 & \multirow{3}{*}{ BG } & \multirow{3}{*}{ LG } \\
\hline \multirow[t]{2}{*}{ Item } & \multicolumn{3}{|c|}{ LI, g } & BG & LG & \multicolumn{3}{|c|}{ NS/B } & BG & LG & \multicolumn{3}{|c|}{ DFF } & & \\
\hline & Min & Max & Average & & & Min & Max & Average & & & Min & Max & Average & & \\
\hline $\mathrm{N}$ & 5.26 & 7.19 & 6.01 & G.95 & C-g & 15.46 & 19.33 & 17.09 & G.90 & Kar. & 56.84 & 70.67 & 65.40 & Aus. & Ashm. \\
\hline S & 3.83 & 5.64 & 4.47 & G.95 & G. 83 & 14.46 & 19.98 & 17.07 & G. 83 & G. 80 & 52.00 & 62.50 & 56.48 & Kar. & Ashm. \\
\hline $\operatorname{Red} \%$ & 17.89 & 33.75 & 25.71 & & & -19.88 & 18.77 & -0.16 & & & - & 25.47 & 13.43 & & \\
\hline \multirow[t]{2}{*}{ Item } & \multicolumn{3}{|c|}{ Micronair reading } & BG & LG & \multicolumn{3}{|c|}{ Length, mm } & BG & LG & \multicolumn{3}{|c|}{ Strength (PI) } & BG & LG \\
\hline & Min & Max & Average & & & Min & Max & Average & & & Min & Max & Average & & \\
\hline $\mathrm{N}$ & 3.42 & 4.85 & 4.17 & C-g & Ashm. & 24.12 & 34.12 & 29.35 & G.90 & Aus. & 8.65 & 10.77 & 9.68 & A-g & Aus. \\
\hline $\mathrm{S}$ & 2.89 & 4.05 & 3.54 & B-g & D-g & 23.29 & 31.28 & 27.32 & G.90 & Kar. & 8.20 & 9.90 & 9.01 & $\mathrm{C}-\mathrm{g}$ & Aus. \\
\hline $\operatorname{Red} \%$ & -7.16 & 25.46 & 14.57 & & & -1.80 & 11.20 & 6.75 & & & -0.15 & 11.75 & 6.93 & & \\
\hline
\end{tabular}

G.=Giza, C-g= C- genotype, Ashm.= Ashmouni, Aus.= Australian genotype, Kar.= Karashinki 
Table 7. Ranks (R), ranks mean (R), the standard deviation of ranks (SDR) and rank-sum (RS) of drought tolerance indices.

\begin{tabular}{|c|c|c|c|c|c|c|c|c|c|c|c|c|c|c|c|}
\hline \multirow{2}{*}{ Genotype } & \multicolumn{12}{|c|}{ Rank } & \multirow{2}{*}{$\begin{array}{c}\mathrm{R} \\
\text { means }\end{array}$} & \multirow{2}{*}{ SDR } & \multirow{2}{*}{$\mathrm{RS}$} \\
\hline & Yp & Ys & SSI & STI & MP & GMP & TOL & YSI & HM & SDI & DI & RDI & & & \\
\hline Giza 80 & 7 & 6 & 3 & 6 & 6 & 6 & 7 & 2 & 6 & 12 & 6 & 1 & 5.67 & 2.81 & 8.47 \\
\hline Giza 83 & 4 & 4 & 9 & 4 & 4 & 4 & 11 & 9 & 4 & 6 & 4 & 6 & 5.75 & 2.53 & 8.28 \\
\hline Giza 85 & 6 & 7 & 12 & 7 & 7 & 7 & 10 & 12 & 7 & 3 & 8 & 12 & 8.17 & 2.79 & 10.96 \\
\hline Giza 90 & 2 & 2 & 6 & 2 & 2 & 2 & 13 & 6 & 2 & 10 & 2 & 7 & 4.67 & 3.77 & 8.44 \\
\hline Giza 95 & 1 & 1 & 7 & 1 & 1 & 1 & 14 & 7 & 1 & 8 & 1 & 8 & 4.25 & 4.39 & 8.64 \\
\hline Giza90*Aus & 3 & 3 & 10 & 3 & 3 & 3 & 12 & 10 & 3 & 5 & 3 & 9 & 5.58 & 3.55 & 9.14 \\
\hline Ashmouni & 10 & 11 & 13 & 11 & 11 & 11 & 6 & 13 & 11 & 2 & 12 & 13 & 10.33 & 3.23 & 13.56 \\
\hline Dandara & 9 & 9 & 11 & 9 & 9 & 9 & 8 & 11 & 9 & 4 & 10 & 11 & 9.08 & 1.88 & 10.96 \\
\hline Karashinki & 12 & 13 & 14 & 13 & 13 & 13 & 5 & 14 & 13 & 1 & 14 & 14 & 11.58 & 4.14 & 15.73 \\
\hline Austuraly & 13 & 12 & 1 & 12 & 12 & 12 & 2 & 3 & 12 & 13 & 11 & 2 & 8.75 & 5.03 & 13.78 \\
\hline A & 5 & 5 & 8 & 5 & 5 & 5 & 9 & 8 & 5 & 7 & 5 & 10 & 6.42 & 1.88 & 8.30 \\
\hline B & 8 & 8 & 4 & 8 & 8 & 8 & 4 & 4 & 8 & 12 & 7 & 3 & 6.83 & 2.59 & 9.42 \\
\hline $\mathrm{C}$ & 14 & 14 & 5 & 14 & 14 & 14 & 1 & 5 & 10 & 14 & 13 & 4 & 9.92 & 4.83 & 14.75 \\
\hline $\mathrm{D}$ & 11 & 10 & 2 & 10 & 10 & 10 & 3 & 1 & 10 & 14 & 9 & 5 & 7.92 & 4.10 & 12.02 \\
\hline
\end{tabular}

$\mathrm{Yp}=$ yield under non-stress, Ys = yield under stress, Stress susceptibility index (SSI), Stress tolerance index (STI), Mean productivity (MP), Geometric mean productivity (GMP), Tolerance index (TOL), Yield stability index (YSI), Harmonic mean (HM), Sensitivity drought index (SDI), Drought resistance index (DI), Relative drought index (RDI).

Correlation of rank with scy/p under irrigation $=0.999$ and under drought stress $=0.993$

However, the picture was different under drought stress in which drought affect lint rather than seeds as mentioned above, the correlation of SCY/P was moderate with lint $\%$ (0.5897), fiber length (0.7248), low and negative with LI (-0.1488) and Micronaire reading (-0.4090) indicating that droughtaffected deposition of cellulose which slightly lowered Micronaire and increase fiber strength. Under normal irrigation LY/P showed correlations with other traits as SCY/P did. While under drought stress the correlation of LY/P was high with lint\%, moderate with $\mathrm{NB} / \mathrm{P}, \mathrm{BW}$ and LI and negative with DFF. The correlation of lint\% under irrigation was high with NBV/p, BW and LI, moderate with NS/B and fiber length, and low with the other traits. However, under stress it was moderate only with LI and low with NB/P (0.3010), BW (0.3788) and NS/B (0.3229). Under irrigation the correlation of $\mathrm{NB} / \mathrm{P}$ was high with LI (0.8123) and moderate with BW (0.6978) and fiber length (0.5401). While under drought $\mathrm{NB} / \mathrm{P}$ gave negative correlations with BW, LI, NS/B, and Micronaire reading, and positive moderate with DFF, fiber length and strength.
The increase in BW under both environments increased NS/B and LI. Concerning fiber length it was increased under irrigation and decreased under drought with increasing BW. It is known that drought stress decrease fiber length.

Micronaire instrument measures fineness and maturity in combined, it measures fineness between genotypes and maturity within a genotype. Low Micronaire reading of a genotype means large number of fibers in unit weight, which increase fiber strength to some extent. Therefore, Micronaire reading negatively correlated with Pressley index under both environments. The results of correlation in general are in line with many researchers (Farooq et al., 2014; Reddy et al., 2015; Khokhar et al., 2017; Nawaz et al., 2019) noted that seed cotton yield has positive genotypic correlation with bolls/plant, boll weight, staple length, strength, and earliness index. Abdel-Monaem et al. (2018) observed positive correlations between yield and each of its components in most cases, while correlations among yield traits were higher in normal irrigation as compared with water stress. 
Table 8. Phenotypic correlation among traits over two years under normal irrigation (above) and under drought stress (below diagonal).

\begin{tabular}{|c|c|c|c|c|c|c|c|c|c|c|c|c|}
\hline Traits & SCY/P & LY/P & Lint $\%$ & $\mathrm{NB} / \mathrm{P}$ & BW & SI & LI & NS/B & DFF & MIC. & Length. & Strength. \\
\hline SCY/P & - & 0.9970 & 0.9199 & 0.9320 & 0.8930 & 0.2339 & 0.8126 & 0.5804 & -0.0227 & -0.2031 & 0.6190 & 0.1170 \\
\hline $\mathrm{LY} / \mathrm{P}$ & 0.7517 & & 0.9458 & 0.9162 & 0.9007 & 0.2135 & 0.82 & 0.5933 & -0.0245 & -0.231 & 0.622 & 0.1043 \\
\hline Lint $\%$ & 0.5897 & 0.8633 & - & 0.8194 & 0.8567 & 0.0886 & 0.7976 & 0.5922 & 0.0679 & -0.3236 & 0.6373 & 0.1005 \\
\hline $\mathrm{NB} / \mathrm{P}$ & 0.8468 & 0.4104 & 0.3010 & & 0.6978 & 0.3653 & 0.8123 & 0.3279 & 0.0363 & -0.1374 & 0.5401 & 0.1731 \\
\hline BW & -0.2292 & 0.4518 & 0.3788 & -0.5776 & - & 0.0833 & 0.6667 & 0.7328 & -0.0383 & -0.2739 & 0.6231 & 0.0630 \\
\hline SI & 0.3150 & -0.0037 & 0.0000 & 0.2848 & $\begin{array}{c}- \\
0.4052\end{array}$ & & 0.6667 & -0.5862 & -0.2635 & 0.4108 & 0.0779 & -0.0945 \\
\hline LI & -0.1488 & 0.5331 & 0.5142 & -0.4820 & 0.9768 & -0.2888 & - & 0.0879 & $0.1150-$ & 0.0 & 0.5128 & 0.0 \\
\hline NS/B & -0.1285 & 0.4567 & 0.3229 & -0.5207 & 0.9206 & -0.5800 & 0.8266 & & 0.1213 & -0.4174 & 0.4566 & 0.1219 \\
\hline DFF & 0.2146 & -0.3699 & -0.2978 & 0.4322 & $\begin{array}{c}- \\
0.8297\end{array}$ & 0.2346 & $\begin{array}{c}- \\
0.8474\end{array}$ & -0.6550 & - & -0.2151 & 0.3552 & 0.4707 \\
\hline MIC & -0.4090 & 0.2828 & 0.2598 & -0.6585 & 0.9683 & -0.4601 & 0.9441 & 0.8404 & -0.8467 & & -0.256 & -0.5866 \\
\hline Length & 0.7248 & 0.3164 & 0.2940 & 0.5359 & $\begin{array}{c}- \\
0.4619\end{array}$ & 0.4141 & $\begin{array}{c}- \\
0.4448\end{array}$ & -0.2607 & 0.5773 & -0.6473 & & 0.4612 \\
\hline Strength & 0.3331 & -0.3009 & -0.2317 & 0.5261 & $\begin{array}{c}- \\
0.8784\end{array}$ & 0.3183 & $\begin{array}{c}- \\
0.8833\end{array}$ & -0.6932 & 0.7322 & -0.9141 & 0.6274 & - \\
\hline
\end{tabular}




\subsection{Path - coefficient analysis}

Path-coefficient analysis is an effective method to partition a correlation to direct and indirect effects and helps the breeder to restrict selection for few important traits and reduce time and effort (Wadeyar and Kajjidoni, 2014). The phenotypic correlation coefficients of seed cotton yield with its contributing traits were partitioned to direct and indirect effects and shown in Table 8 . Seed cotton yield/plant is a result of lint yield/plant, bolls/plant, number of seeds/boll and seed index.

The correlation coefficient of lint yield / plant with seed cotton yield / plant (Table 8) was positive and very large in magnitude (0.9970) under normal irrigation, and 0.7517 under drought stress. However, the direct effect of LY/P on SCY/P was high (0.6540) under normal irrigation, and low (0.0891) under drought stress (Table 9). The analysis indicated that under normal irrigation selection should be paid on LY/P, NB/P and NS/B, and for NB/P

and NS/B under drought stress. The indirect effect of LY/P via SI was low and negligible.

Partitioning the correlation coefficient NB/P with seed cotton yield to their direct and indirect effects indicated that the direct effect of NB/P was the highest (0.9991) under stress rather than under normal irrigation (0.2376). The indirect effect of NB/P on SCY/P was high under irrigation via LY/P (0.5991) and low under drought (0.0365). The indirect effects of NB/P via NS/B and SI were low. Therefore, selection for NB/P under stress and for LY/P under irrigation should be considered.

Partitioning correlation of NS/B and SI with SCY/P indicated that the direct and indirect effects differed greatly under both environments. The direct effect of NS/B and SI were high under drought and low under irrigation, and vice versa concerning LY/P.

It could be concluded that the direct and indirect effects of SCY/P components varied greatly under both environments, and LY/P, $\mathrm{NB} / \mathrm{P}$ and NS/B should be considered as selection indices under normal irrigation, NB/P and NS/B under stress when selection practiced for SCY/P. Farooq et al (2014) found positive direct effect of boll weight on seed cotton yield / plant. Ahsan et al (2015) found that bolls plant- ${ }^{1}$ had maximum direct effect (0.945) followed by the boll weight (0.062), seed index (0.007) and lint index (0.040). Wadeyar and Kajjidoni (2014) and latif et al. (2015) noted that the correlation and path analysis together indicated that number of bolls / plant and boll weight should be considered when selection practiced for seed cotton yield / plant. Joshi and Patil (2018) found that number of bolls/plants had positive indirect effect on seed cotton yield/plant, seed index, lint index, fiber strength etc. Boll weight was responsible for high yield through seed index and lint index. 
Table 9. Path coefficient analysis under normal irrigation and water stress conditions.

\begin{tabular}{|c|c|c|}
\hline & Normal irrigation & Drought stress \\
\hline $\mathrm{SCY} / \mathrm{P} v s \mathrm{LY} / \mathrm{P}$ & $\mathrm{r}=0.9970$ & $\mathrm{r}=0.7517$ \\
\hline Direct effect, P15 & 0.6540 & 0.0891 \\
\hline Indirect effect, NB/P (r12P25) & 0.2177 & 0.4100 \\
\hline Indirect effect, NS/B (r13P35) & 0.1029 & 0.2539 \\
\hline Indirect effects, SI (r14P45) & 0.0224 & -0.0013 \\
\hline Total & 0.9970 & 0.7517 \\
\hline $\mathrm{SCY} / \mathrm{P} v s \mathrm{NB} / \mathrm{P}$ & $\mathrm{r}=0.9320$ & $\mathrm{r}=0.8468$ \\
\hline Direct effect, P25 & 0.2376 & 0.9991 \\
\hline Indirect via LY/P (r12P15) & 0.5991 & 0.0365 \\
\hline Indirect via NS/B (r23P35) & 0.0570 & -0.2894 \\
\hline Indirect via SI (r24P45) & 0.0383 & 0.1006 \\
\hline Total & 0.9320 & 0.8468 \\
\hline $\mathrm{SCY} / \mathrm{P} v s \mathrm{NS} / \mathrm{B}$ & $\mathrm{r}=0.5804$ & $\mathrm{r}=-0.1285$ \\
\hline Direct effect, P35 & 0.1735 & 0.5559 \\
\hline Indirect via LY/P (r13P15) & 0.3879 & 0.0406 \\
\hline Indirect via NP/B (r23P25) & 0.0780 & -0.5202 \\
\hline Indirect via SI (r34P45) & -0.0590 & -0.2048 \\
\hline Total & 0.5804 & -0.1285 \\
\hline $\mathrm{SCY} / \mathrm{P} v s \mathrm{SI}$ & $\mathrm{r}=0.2339$ & $\mathrm{r}=0.3150$ \\
\hline Direct effect, P45 & 0.1050 & 0.3532 \\
\hline Indirect via LY/P (r14P15) & 0.1396 & -0.0003 \\
\hline Indirect via NB/P (r24P25) & 0.0868 & 0.2845 \\
\hline Indirect via NS/B (r34P35) & -0.0975 & -0.3224 \\
\hline Total & 0.2339 & 0.3150 \\
\hline Residual effect & 0.0360 & 0.2171 \\
\hline
\end{tabular}

\section{References}

Abdel-Monaem, M.A., Ghoneima, M.H., ELMansy, Y.M. and EL-Shazly, M.W. (2018) 'Evaluation of some Genotypes under Water Stress for some Yield and Fiber Quality Properties in Cotton (Gossypium barbadense L.)' J. of Plant Production, 9 (5), pp. 477-483.

Ahsan, M.Z., Laghari, M.A., Bhutto, H., Soomro, A.W., Majidano, M. and Malik, T.H. (2015) 'Genetic Variability in different biometric traits of upland cotton genotypes' Int. J. Bio. Biotech.,12, pp,607-612.

Alishah, O. and Ahmadikhah, A. (2009) 'The effects of drought stress on improved cotton varieties in Golesatn Province of
Iran. International J. Plant Prod., 3(1). pp, 17-26.

Amein, M.M., Masri, M.I., EL-Adly, H.H. and Attia S.S. (2020) 'Correlation and path analysis for yield components traits in Egyptian cotton genotypes (Gossypium barbadense L.)' Plant Archives, 20, pp, 803-806.

Bakhsh, A., Rehman, M., Salman, S. and Ullah, R. (2019) 'Evaluation of cotton genotypes for seed cotton yield and fiber quality traits under water stress and nonstress conditions' Sarhad J. of Agric., 35(1) pp, 161-170.

Blake, G.R., and Hartge, K.H. (1986) 'Bulk Density. In A. Klute (ed.) Methods of Soil Analysis. Part 1 - Physical and Mineralogical Methods Second Edition' 
American Society of Agronomy, Madison WI

Bouslama, M. and Schapaugh, W.T. (1984)

'Stress tolerance in soybean. Part 1:

Evaluation of three screening techniques for heat and drought tolerance' Crop Science, 24, pp, 933-937.

Cassel, D.K., and Nielsen, D.R. (1986) 'Field Capacity and Available Water Capacity. In Page, A.L., R.H. Miller and D.R. Keeney (eds.) Methods of Soil Analysis Part 2: Chemical and Microbiological Properties' Second Edition. Agronomy Society of America, Madison, WI. مطلوب العدد ورقم الصفحات

Chakherchaman, S.A., Mostafaei, H., Imanparast, L., and Evasion, M.R. (2009) 'Evaluation of drought tolerance in lentil advanced genotypes in Ardabil region' Iran J. Food Agric. Env., 7(3-4): 283-288.

Dewey, D.R. and Lu, K.H. (1959) 'A correlation and path-coefficient analysis of components of crested wheatgrass seed production' Agron. J., 51, pp,515518.

Farooq, J., Anwar, M., Riaz, M., Farooq, A., Mahmood, A., Shahid, M.T., Rafiq, S.M. and Llahi, F. (2014) 'Correlation and path coefficient analysis of earliness, fiber quality and yield contributing traits in cotton (Gossypium hirsutum 1.)' J. Anim. Plant Sci., 24(3), pp, 781-790.

Farshadfar, E. and Javadinia, J. (2011) 'Evaluation of chickpea (Cicer arietinum $\mathrm{L}$ ) genotypes for drought tolerance' Seed \& Plant Improvement J., 27(4), 517-537.

Fernandez, G.C.J. (1992) 'Effective selection criteria for assessing plant stress tolerance' In: Proceeding of the
International Symposium on adaptation of vegetable and other food crops in temperature and water stress. Publication, Taiwan, pp, 257-270.

Fischer, R.A. and Maurer, R. (1978) 'Drought resistance in spring wheat cultivars. I. Grain responses' Australian Journal of Crop Sci., 29, pp, 897-912.

Fischer, R.A., Rees, D., Sayre, K.D., Lu, Z.M., Condon, A.G., and Saavedra, A.L. (1998) 'Wheat yield progress associated with higher stomatal conductance and photosynthetic rate and cooler canopies' Crop Sci., 38, pp, 1467-1475.

Fouad, H.M. (2018) 'Physiological traits and drought tolerance indices in advanced genotypes of bread wheat (Triticum aestivum L)' Egypt. J. Agro., 40, pp,145 $-154$

Gao, M., Snider, J.L., Bai, H., Hu, W., Wang, R., Meng, Y., Wang, Y., Chen, B. and Zhou, Z. (2020) 'Drought effects on cotton (Gossypium hirsutum L.) fiber quality and fiber sucrose metabolism during the flowering and boll-formation period'[one line https://doi.org/10.1111/jac.12389] .

Gee, G.W., and Bauder, J.W. (1986) 'Particle Size Analysis’ In Page, A.L., R.H. Miller and D.R. Keeney (eds.) Methods of Soil Analysis Part 2: Chemical and Microbiological Properties. Second Edition. Agronomy Society of America, Madison, WI.

Hamoud, H.M., Soliman, A., Eldemery, M.S.M. and Abdellatif, K. F. (2016) 'Field performance and gene expression of drought stress tolerance in cotton (Gossypium barbadense L.)' Biotechnology $J$. International, 14(2), pp, 1-9.

Israelson, O.W. and Hansen, V.E. (1962) 'Flow of Water into and Through Soils' Irrigation Principles and Practices. $3^{\text {rd }}$ 
Edition, John Wiley and Sons, Inc., New York, N. Y., U.S.A.

Joshi, V. and Patil, B.R. (2018) 'Correlation and path coefficient analysis in segregating population of Upland cotton (Gossypium hirsutum L.)' Int. J. Curr. Microbiol. App. Sci., 7(8), pp, 125-129.

Khokhar, E.S., Shakeel, A., Maqbool, M.A. Anwar, M.W., Tanveer, Z. and Irfan, M.F. (2017) 'Genetic study of cotton (Gossypium hirsutum L.) genotypes for different agronomic, yield and quality traits' Pakistan J. Agric. Res., 30, pp,363-372.

Lan, J. (1998) 'Comparison of evaluating methods for agronomic drought resistance in crops' Acta Agriculturae Boreali-Occidentalis Sinica, 7, pp, 8587.

Mahdi, Z., Mohammadifard, Gh. R., Bazrafshan F. and Zadehbagheri, M. (2014) 'Evaluation of cotton (Gossypium hirsutum L.) genotypes to drought stress' Inter.l J. Biosc., 4 (12), pp, 158 166.

Mahdy, E.E., Ahmed, A.A., Ali, E.A. and Talat, A.R. (2008) 'Evaluation of nine Egyptian cotton cultivars for drought tolerance in clay and sandy new reclaimed soils' Assiut J. of Agric. Sci., 39(2), pp, 17-32.

Malik, T.A., Sanaullah and Malik, S. (2006) 'Genetic linkage studies of drought tolerant and agronomic traits in cotton' Pak. J. Bot., 38(5), pp, 1613-1619.

Miller, P.A., Williams, J.C.Jr., Robinson, H.F. and Comstock, R.E. (1958) 'Estimates of genotypic and environmental variances and covariances in Upland cotton and their implication in selection' Agron. J., 50, pp,126-131.
Nawaz, B., Sattar, S. and Malik, T.A. (2019). Genetic analysis of yield components and fiber quality parameters in Upland cotton. Int. Multidiscip Res. J., 9: 13-19.

Rahman, M., Ullah, I., Ahsraf, M., Stewart, J.M., Zafar, Y. (2008) 'Genotypic variation for drought tolerance in cotton' Agron. Sustain. Dev. 28, pp, 439-447. DOI: 10.1051/agro:2007041.

Reddy, K.B., Reddy, V.C., Aiuned, M.L., Nadiu, T.C.M. and Srinivasarao, V. (2015) 'Correlation and Path coefficient analysis in upland cotton (Gossypium hirsutum L.)'. Int. J. Pure App. Biosci.,3 (3), pp,70-80.

Rosielle, A.A. and Hamblin, J. (1981) 'Theoretical aspects of selection for yield in stress and nonstress environments' Crop Sci., 21, pp, 943946.

Sahito, A., Baloch, Z.A., Mahar, A.S., Otho, A., Kalhoro, S.A., Ali, A., Kalhoro, F. A., Soomro, R.N. and Ali, F. (2015) 'Effect of water stress on the growth and yield of cotton crop (Gossypium hirsutum L.)' American J. of Plant Sci., 6, pp, 1027-1039.

Shilpa, B., Pusadkar, P. and Chandrasekhar, C.N. (2020) 'Assessment of fiber quality and yield allied parameters under drought condition in Cotton' Int. J. Curr. Microbiol. Sci., 9(4), pp,12371244.

Singh, Ch., Kumar, V.I., Prasad, V., Patil, R. and Rajkumar, B.K. (2016) 'Response of Upland cotton ( $G$. hirsutum L.) genotypes, to drought stress using drought tolerance indices. J. Crop. Sci., Biotech., 19(1): 53-59.

Sio-Se Mardeh, A., Ahmadi, A., Poustini, K., Mohammadi, V. (2006) 'Evaluation of 
drought resistance indices under various environmental conditions' Field Crops Research, 98, pp, 222-229.

Steel, R.G.D., Torrie, J.H. and Dicky, D.A. (1997) 'Principles and Procedures of Statistics. A Biometrical Approach' $2^{\text {nd }}$ Ed. McGraw Hill Book Company. Inc. New York, NY.

Tulasi, J., Lal, M.A., Murthy, J.S.V. and Rani, Y.A. (2012) 'Correlation and path analysis in American cotton' Electronic Journal of Plant Breeding, 3(4), pp.1005-1008.

Turkey, H.Sh. (2012) 'Estimation of genetic variability in some cotton crosses (Gossypium barbadense, L.) under water stress'. M.Sc., Thesis, Fac. Of Agric., Kafr El-Sheikh, Univ., Egypt.
Veesar, N.F., Baloch, M.J., Kmubher, M.B. and Chachar, Q.D. (2018) 'Field screening of cotton genotypes for drought tolerance on the basis of yield and fiber traits' Sindh Univ. Res. Jour. (Sci. Ser.), 50 (1), pp, 45-52.

Wadeyar B.S. and Kajjidoni, S.T. (2014) 'Phenotypic and genotypic correlation and path analysis in the advance breeding lines of desi cotton' Molecular Plant Breeding, 5(12), pp, 1-4

Yehia, W.M.B. (2020) 'Evaluation of same Egyptian cotton (Gossypium barabadense L.) Genotype to water stress by using drought tolerance indices' Elixir Agriculture, 143, pp, 54133-54141. 